\title{
Főiskolai hallgatók rekreációs tevékenységei
}

\author{
10.21486/recreation.2011.1.4.3
}

A cikkünkben 150 fő szolnoki főiskolás hallgató jellemző szabadidős tevékenységét és utazási szokásaikat vizsgáltuk. A TV nézés gyakorisága, a TV nézésre forditott idő és sportolás közötti kapcsolatot is elemeztük. Az utazási gyakoriságot, a desztinációválasztás motivációját elemeztük. Megállapítottuk, hogy a főiskolai hallgatók rendelkeznek napi több óra szabadidővel. A szabadidős tevékenységeik között dominánsan jelentkezik a tv-nézés, a sportolás, és az utazás. Észrevehetjük azt az érdekességet, hogy a gyakoriságnál nem, míg az alkalmankénti TV-nézés ideje és a rendszeres testmozgás között már szignifikáns a kapcsolat. Azok a hallgatók, akik naponta 1-2 órát sportolnak, lényegesen kevesebb időt töltenek el a TV előtt azon társaikhoz képest, akik nem sportolnak. A hallgatók 92 százaléka évente legalább egyszer utazik. Az ifjúsági turizmus résztvevői igen árérzékenyek. Előnyben részesítik a desztináció-választásnál az utazás kedvező árát. Kulcsszavak: szabadidős tevékenységek, ifjúsági turizmus, utazási szokások, szabadidő-eltöltési szokások

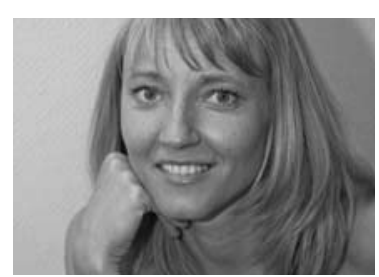

DR. HABIL. MÜLLER ANETTA ÉVA

Titulusa: főiskolai tanár Munkahelye: Eszterházy Károly Főiskola Levelezési címe: 5000, Szolnok, Konstantin út. 59. I.em.3. E-mail címe: muller@ektf.hu Érdeklődési köre: sport, kutatás Társszerzők: SZÉLES-KOVÁCS GYULA Munkahelye: Eszterházy Károly Főiskola E-mail: szkovacs@ektf.hu SERES JÁNOS Munkahelye: Eszterházy Károly Főiskola E-mail: seres @ektf.hu KRISTONNÉ DR. BAKOS MAGDOLNA Munkahelye: Eszterházy Károly Főiskola E-mail: kristonmagdi@ektf.hu
Pikó Bettina szerint „az életmód olyan kerete életünknek, amely mindennapi tevékenységeinket foglalja egybe, szorosan összefügg identitásunkkal, és meghatározza a társadalomban és a kisebb csoportokban kijelölt helyünket ${ }^{1}$." Meghatározza tehát személyiségünk alapjait, ugyanakkor különböző formában és módon beilleszt minket a társadalomba. Az életmód igen összetett fogalom. Ugyanakkor lehetőségek tárháza is, amely döntés meghozatalára kényszerít minket. A választék pedig igen sok. Sokszor éppen ez okozza a gondot, különösen a mai fiatalok számára. Jó döntést hozni nem egyszerü. A sok alternatíva mérlegelése közben pedig akaratlanul is belebonyolódhat az ember a döntéshozásba. Jó példa lehet erre a pályaválasztás okozta esetleges problémák. Talán ez az egyik legfontosabb döntés a fiatalok életében, hiszen ekkor teszik meg az első lépést a nagybetűs ÉLET felé, és ugyanekkor le is zárnak egy ugyancsak nagyon fontos szakaszt.

Pikó Bettina (szerk.) [2005]: Ifjúság, káros szenvedélyek és egészség a modern társadalomban. Budapest, L’Harmattan Kiadó, 30. o. Az idézett mủ a továbbiakban: Pikó Bettina (szerk.) [2005] 


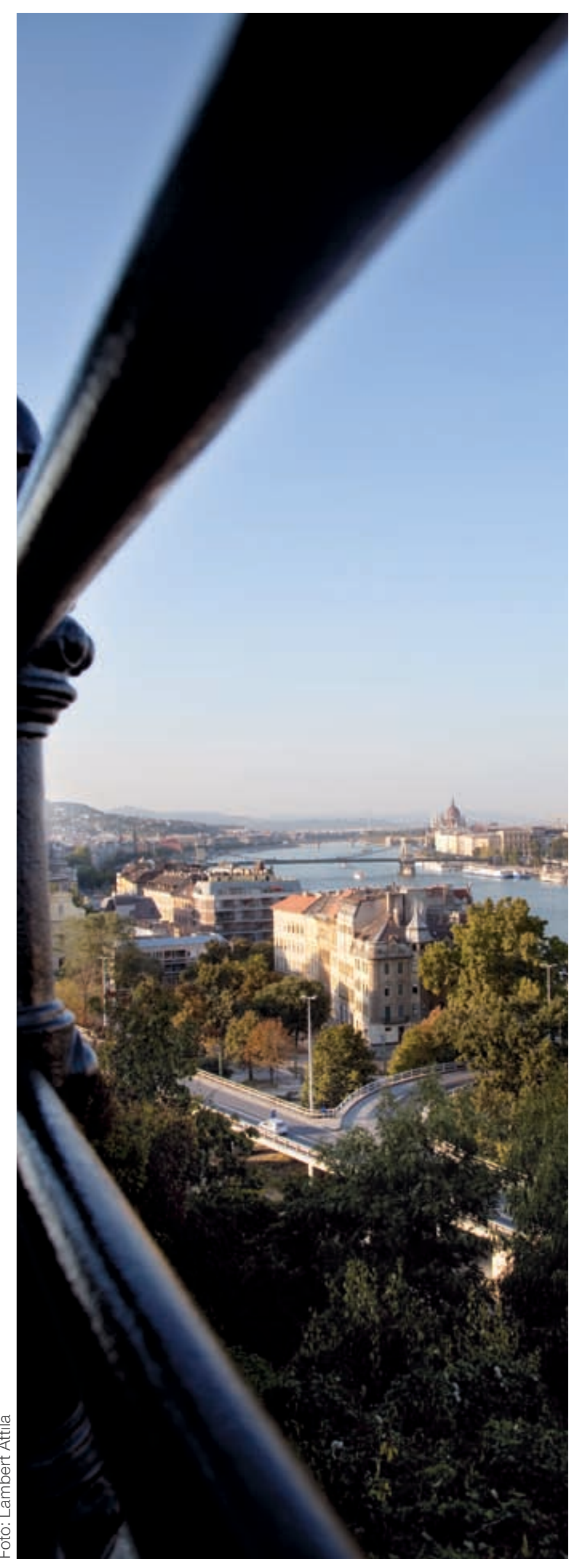

Az ember életét, életmódját nagyban befolyásolja az, hogy ho lakik, milyen az adott ország életfelfogása, mentalitása, kultúrája. Az eletmodhoz szorosan hozzatartozik a szabadido-eltöltés. E kettó elvalaszzhatatlan egymástol. A szabadidó mibenletetet számos kutató meghatározta már. Szánto Mikiós szabadidó-fogalma a kovetkezo. „A szabadido,, mint idokerete a munkán kivulli idonek az a ressze, amely az anyagi-tehat gazdasági, tarsadalmi, fiziologiaikenyszer alapjann fettettenul szukséges elfoglattságok idejejn felul Kênyszeren kival esó tevekenységekre fennmarad. "Reichin Krisztina a kovetkezoképpen definialja: „A szabadidó mindazon foglatatosságok osszessége, amelyekben az egyén oonkènt vesz reszz, akár azent, hogy kipinenje magat, vagy szórakozzek, vagy Tuada hépesolat apolja, esét gy tovabb kepezze magat."

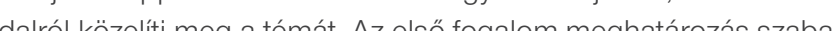
lon

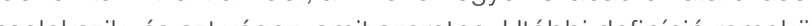
mán

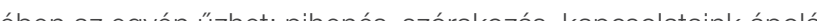

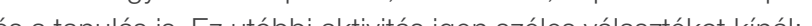

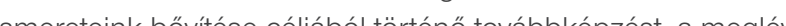
hobbinkban lévő fejlődést vagy akár állóképességünk javitása cét jából fakadó továbbképzést, magyarán sportolást.

Wolfgang Nahrstedt (2000) a welness koncepcíjíban kiemel Wolfong Nahrsted (2000) a wión réciós tevékenysécek az egészségünk megörzése érdón A sporttevékenység rekreációban betölẗ̈̈t szerepét Dumat der (1968) is méltatija. Szerinte a sporttevékenysés nem csupán fiatalok testi és jellembeli formálásának eszköze lehet hanem az fontos, hogy megszerescék ezt a tevékenységet és később felnôt korukban az életmód elemévé váljon.

Fontos a szabadidő, az utazás és a turizmus kapcsolata is, hiszen ezek elválaszthatatlanok egymástól. Csakis a rendelkezésünkre álló idöben tehetiük meg, hogy elutazunk a kedvelt helyszinünkre.

A turizmus több kisebb egységre bontható. Ezen egységek közül az egyik a szabadidő-turizmus. A szabadidő-turizmus az állandó lakáson kivüli szabad idôben végzett és szabadon választott tevékenységek összessége, amelyeket az ember változatosság-génye motivál."토 E turizmuság kapcsán több tevékenységet is meg lehet nevezni. Azok tartoznak ide, amiket az ember szivesen müvel szabadidejében: sportolás, kirándulások, különféle hobbik, fürdőlátogatás.

Nem könnyủ megállapitani, hogy pontosan kik tartoznak ebbe a csoportba. A Turizmus trend egyik cikkében ez olvasható: „A WTO definíciója szerint a 16 és 26 év közötti utazók alkotják az if

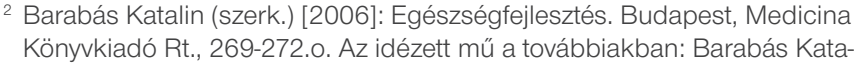
Könyvkiadó Rt., 2

Szántó Miklós [1967]: Életmód, müvelödés, szabadidő. Budapest, Aka démiai Kiadó, 13. o. Az idézett mú a továbbiakban: Szántó Miklos [196]
Reichlin Kristina [2007]: Szabadidó ismeretek. Budapest, BGF Kereske delmi, Vendéglátóipari és Idegenforgalmi Fóiskolai Kar, 6.0 .

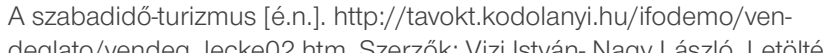
dátuma: 2009. október 11 .

Juray Tünde [2007]: A jövő utazói. Turizmus trend. 2007. június. 34-35. P. júsági turizmus korcsoportját."ํㅡㄹ Más definiciók másképpen húzzák meg a korhatárvonalat. Annyiban viszont egyeterrthetünk, hogy ez az a koroszaly, am ely tehát ebbol a szempontbol tejesen erthetó ez a besorolás. Az ifjú-

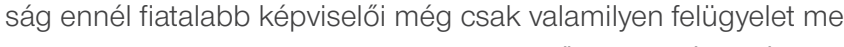

A KUTATÁS CÉLJA

A kutatás fổ célia ismertetni a 20-24 éves iffú felnőttek szabadidő-ettöltési és utazási szokásait és desztináció-válastás motivációit. E cél megvalósitásához a primer kutatás egyik tipusát, kérdőives kutatást végeztünk. A kutatás 2009 tavaszán zailott (A kérdöives felmérésben Borbás László (2010) főiskolai hallgató vett részt).

Hipotézisek

A televiziózźssal elöltöttrt idő szignifikánsan befolyásolia a fiatalok sportolásra és kulturális tevékenységekre fordított idejét. Mivel a fiatalok alacsony diszkrecionális jövedelemmel rendelkeznek, így ez jelentőss mértékben befolvásolia az utazási szokásaikat. A desztináció-válastás motivációját leginkább a kedvező ár befolvásolja.

A minta szocio-demográfiai adatai

A minta ismertetését a fiúk és a lányok nemenkénti arányával kezdAüminta ismertetését a fiúk és a lányok nemenkénti arányával kezdfót jelent), 77,3 százaléka pedig lány (116 fö). Összzességében elmondható, hogy a 140 hallgatóból (112-en élnek 10.000-nél nagyobb lélekszámú városban, ami kereken 80 százalékos arányt mutat.

EREDMÉNYEK

A megadott válaszok alapján a hallgatóknak mindössze 9,3 százaléka rendelkezik 1-2 óránál kevesebb szabadidővel, de előfordulhat, hogy ezek között akad olyan is, aki egyáltalán nem engedheti meg magának a pihenést. A minta egészéhez képest ők vannak elenyésző mennyiségben. A fiatalok nagyobbik része legalább napi 1-2 szabad órát be tud iktatni a napirendjébe. Akadnak viszont olyanok is (42\%), akik 3-4 órányi szabadidővel bizonyára számos aktivitást tudnak végezni, illetve nyugodtan tudnak élni a hobbijuknak. A válaszadók valamivel több, mint harmada rendelkezik napi 1-2 órányi szabadidővel. 22 fiatalnak, azaz a hallgatók 14,7 százalékának még 3-4 óránál is több a rendelkezésre álló ideje naponta.

Külön kérdés foglalkozott azzal, hogy kikkel töltik szivesen szabad perceiket a hallgatók. Erre a kérdésre több választ is lehetett adni. Altalánosságban megállapitható, hogy a hallgatok nagy többsége kizárólag másod- vagy többedmagával szeret lenni szabadidejében. A válaszadók közül mindössze 16 fő (ez 10,7 szazaleknak felel meg) jelezte a kérdốíben, hogy szabad perceiben egyedül is szeret lenni, viszont ők e válaszlehetöség mellett még mást is aláhúztak, ami azt bizonyitja, hogy ök sem zärkoznak el teljes mértékben a világtól. A kérdésre válaszolók, egyuttal azt is „elarulták", hogy párkapcsolatban élnek-e vagy sem. Ez alapján megállapitható, hogy a 150 megkérdezett hallga tok kozul valamivel több, mint háromnegyedének (75,3 százalekának) volt a megkerdezes pillanataban baratja illetve barătnoje, akivel szivesen töti el idejet. Ezek mellett a tanulok jelolhettek még a csalaadtagokat, baratokat es/vagy kortarsakat is. Ezeket válaszlehetoségeket illetóen változó eredmények születtek. A valaszadok majdnem kétharmada $(65,3 \%)$ jelölte meg valaszkên
Mennyi szabadidővel rendelkezel?

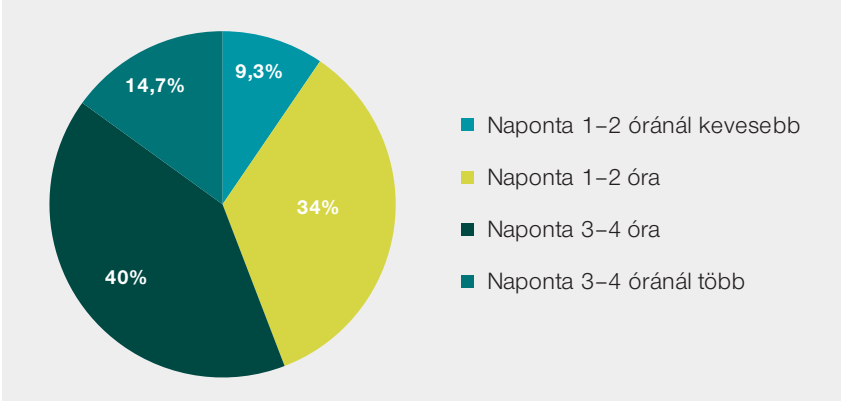

Milyen gyakran nézel TV-t?

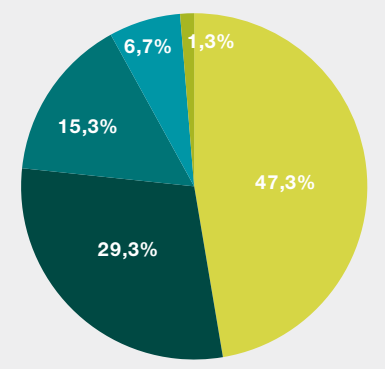

Hetitobb alkalommal 4410

- Hetiegy két alkalommmal 23

- Kevesebb mint heti egy-két

- Nem nézek TVt: 2 tô

2 A TV-nézés gyakorisága

Mi alapján választasz uticélt?

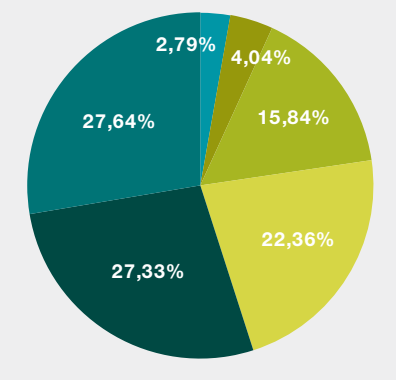

TV-ben láttad 9 fó

- Prospektus alapián 13 fó

Ismerósök ajänlották 51 to

- Természeti adottságok 88 tô

- Kedvezöár 89 fó

Különf́le tényezők szerepe a hallgatók utazási döntésében

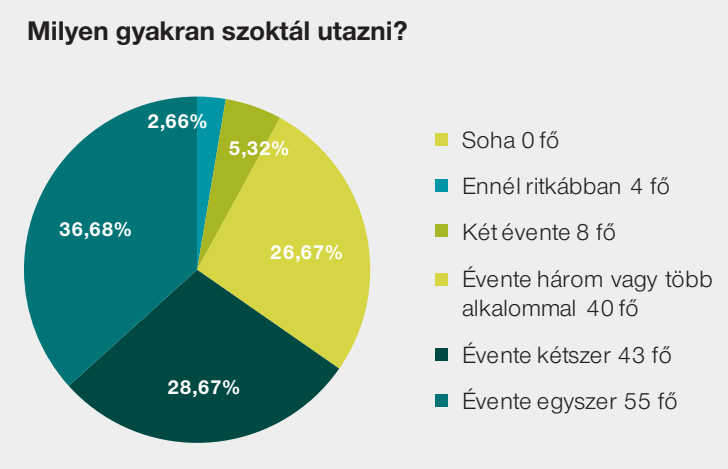

4 A hallgatók utazási gyakorisága 
a családjukat. Kiemelkedően sokan, a hallgatók 82,7 százaléka barátaira illetve barátnöire fordítja munkán kivüli idejét. Ezekbâ a szamadatokból is észre lehet venni, hogy sok az átfedés, azaz a halligatôk nagyobbik rèsze toobb vâlaszt is aláhúzott. Elöford olyan eset is, hogy a diák minden valaszt aláhúzott. A kortársakán nagy, kevesen jelotek meg (mindossze 6 ro, a valaszadok 4 szazaleka). A kutatás alapján az derul $k$ i, hogy, a fiatal szeretnek olyan emberekkel baratkozni, akik kozel ugyanolyan gondolkodás óddal rendelkeznek, es hasono vagy egyazon korszzlalyba tartoznak. Kevess olyan hallgató voll, akiknek bor

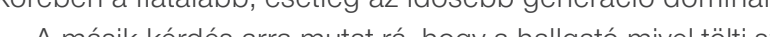
A másik kerdés arra mulat rá, hogy a hallgalo mivel tolti szabadidejet. A kerdés kaposán azt relteloztuk, hogy a hallgatok csok olyan ked ú Rengeteg valasz sz loletet. A valaszadok majdn on múnada (32\%)

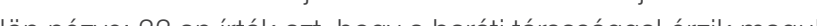

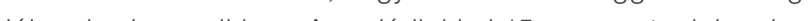

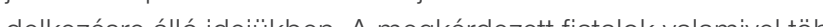

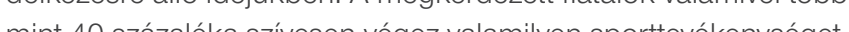
szabadicíben. Egészen pontosan 61 tö szert sportoni A logki-

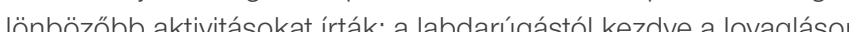
át egészen az aebobig A kutat́s alajín a hallgatók átal bét egyik leggyakoribb tevékenyś́g a sport

Igen sokan végeznek valamilyen kulturális tevékenységet. Ebbe

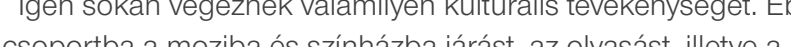
zenehallgáśt vélezthetták. A 150 hallgató Köz̈̈l mindössze 10

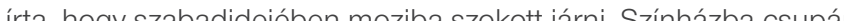
egr hallgató ír nagyohb rendszeressé́g el. Viszont 32 en a megkérdezettek 21 százaléka vesz a kezébe valamilyen könnvet, ha megteheti. A kulturális tevékenységekhez sorolt aktivitások közu ez számitott a legnépszerübbnek. 14 fiatal tölti szabadidjét zen hallgatással. Ezen kivül egy-egy tanuló írta az éneklést, illetve a müvelödést mint végzett aktivitást Összesen tehát 59 megkérde zett (39,3\%) folytat valamilyen kuttúríval kapcsolatos elfoglaltságot. Viszonylag sok hallgató (24 fö, azaz a válaszadók 16 százalóka) választotta az utazást kirándulást és a túrázást mint aktív időeltöltést. Természetesen ezekből a válaszokból nem derült ki. hogy belföldön vagy külf̈̈ldön utaznak inkább. Mivel azonban szabadidóben végzett aktivitásokról van szó ezért inkább a belföld utazások, kirándulások, túrázások a valószinúbbek, mert ezek ke vesebb utazási idót igényelnek és sokszor olcsóbbak is. Fentebb már esett szó az ifiúsági turizmusról

Az aktiv szabadidős programok népszerüsége mellett nem ma radnak el a passzivi cselekvések sem. Összesen 47 hallgató írta vála szában a TV-nézést és az internetböngészést, ami a mintának a 31 százaléka. Elöbbit 23-an, utóbbit 24-en irták. A megkérdezettek 12,6 százaléka, azaz 19 fő választotta a pihenést, mint szabadidó-ltöltést. 13 tanuló szabadidoos „tevékenységként” az alvást írta. Kilencen szoktak nagyobb rendszerességgel valamilyen szórakozási tevékenységet üzni. Ezek közül akadt olyan, aki a „bulizást” valastotota

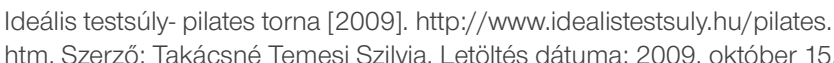
a: 2009. október s. 15 . ?ID=sportagrol_jatekszzabalyok.htm. Letöttés dátuma: 2009. október 15.
A SPORTTAL KAPCSOLATOS A

ményeket ismertetakk. Kulon kerdés foglalkozott azzal, hogy van-e lehetöségük a hallgatóknak saját lakhelyukon sportoni. A megkerdezettek elsôp 'ó tobséggel ( 134 10, 89,3\%) valaszoltak ,igennel. Tizenhatan

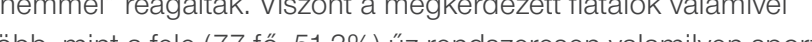
óbb, mint a fele (7f $10,51,3 \%$ ) úz rendszeresen valamilyen sportevekenyseget. Ebbol az derul ki, hogy bár sokaknak lenne leheosezuk a testmozgása, kulonbozo okokbol krolyollag megsem mozognak. Fon hár ím, hogy a lanulók kb. 40 százaleka

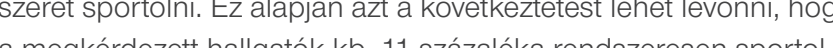
de nem szereti a testmozgást, vagy csak valamilyen kényszer hatá sára sportol (például testtartás javitása miatt).

A különböző sportaktivitások közül az aerobik tünt a legerübbnek. A rendszeresen sportolók majdnem harmada , Az aerobik mellett még a futás (13 fö), a labolańgás (11 fö).

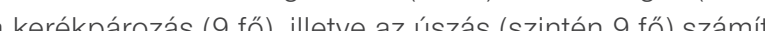
népszerübb sporterékenységnek a hallgatók között. Termeszetesen vannak más mozáśtipusok is amit a rendszemesportolók üznek, de ezek elenvésző számban fordunak elö. Hatan a konditeremben szoktak rendszeresen edzeni. Több olyan sport is akadt, amelyet öten üznek. Ezek a tenisz, a fit

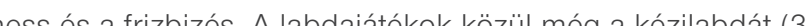
tö) és a kosárlabdát (2 fö) említették. Szerepelt a mintában olyan hallgató is, aki nem veti meg a küzdősportokat, illetve a harcmúvészetet. Három hallgató említette a taichit, a thaibok szot és a taekwon dot Van olyan hallgató, aki olyan különleg sportnak a szerelmese, mint a pilates. Ez a sport elösorban törzsi izmokat erősiti. Olyan fiatal is benne volt a mintában, aki a spinning-nek és a spinracing-nek hódol. Említették még áncot és a néptáncot is mint kedvelt aktivitást. Különhöző té sportágak is szerepeltek az értékelésben. Sielni ketten szoktak rendszeresen. Volt olyan hallgató, aki szívesen korcsolya zik. Olyan tanuló is közremüködött a kérdöiv kitölésében, aki szivesen száll nyeregbe, és lovagol egyet. Valaki az iját aizza fel, és próbál minél több nyilvesszőt a céltáblába lőni. Más a szabadban szeret gyalogolni. Megint más a lábtoll labdának Ez a sport ugyanolyan, mint a tollaslabda azzal a különbségge hogy ütök helyett a lábukkal továbbitiák a labdát a játékosok. Akadnak olyan hallgatók is, akik a rendszeres mozgás mellett még valamelyik sportegyesületnek is a tagjai. A megkérdezettek közül mindössze 11 fö vesz részt ilyen egyesületben. Megállapítható, hogy a 150 hallgató közül 71-en (az öszszesnek a 47,3 százaléka) napi rendszerességgel ülnek le a TV képernyöje elé, ami jól jelzi a népszerüségét. Amennyiben pedig figyelembe vesszük a többiek válaszait is, még nagyobb meggyo ződést kaphatunk. 44 fő többszöri rendszerességgel szokott TV-t nézni hetente. További 23 hallgató hetente egy vagy két alkalma szeret a televizió nézésére szánni. Ha mindezeket az adatokat figyelembe vesszük, az derül ki, hogy 138 megkérdezett (92\%) biztosan leül a TV elé legalább heti egy-két alkalommal. A ,mara dék" közül 10 fö ritkábban, kevesebb, mint heti egy-két alkalommal ül le a képernyỏ elé. Két hallgatót pedig egyáltalán nem hozza lázba ez a szabadidös tevékenyseg.

\section{„A főiskolai hallgatók rendelkeznek napi több óra szabadidővel. A szabadidős tevékenységeik között dominánsan jelentkezik a tv-nézés, a sportolás, és az utazás."}

Összehasonlitó elemzést végeztünk a TV-nézés gyakorisága és sportolás közzött A vizsgálatot Chi2-próbának vetettük alá. Ennek eredménye a következő lett. Azon hallgatók közül, akik rendszere sen sportolnak (77 fö), 70-en kapcsolják be a televíziót legalább heti egy-két alkalommal (ez 90,9 százzléknak felel meg). Míg a nem sportoló fiatalok közül (73 fö) 68-an néznek televiziót legalább he tente egy-két alkalommal, amely 93,2 százalékot jelent. Láthatjuk hogy a hallgatók száma és a százalékok között alig van eltérés. Ez a kapcsolat tehát nem bizonyult szignifikánsnak $(p>0,005)$.

Amennyiben az alkalmankénti TV-nézés idejét is összehasonlifijuk a rendszeres sportóśsea a fentebb már eml'tett módszer segítségével akkor a következö eredményt kapiuk:

Azon megkérdezettek közül, akik rendszeresen végeznek testmozgást (77 fö), 59-en alkalmanként mindössze egy-két órát vagy még ennél is kevesebb időt forditanak TV-nézése, amely 76,6 százalékot jelent. A rendczeresen nem sportolák közïl (73 fö) 38 -an szánnak alk tanként ugyanennyi idót erre a tevékenységre amely 52 százzalékot jelent A különbség ennnél az esetnél már ielentős. A kapcsolat ez esetben már szignifikánsnak bizonyult $(p<0,005)$. Észrevehetiük azt az érdekességet, hogy a gyakorisánál nem mig az alkalmankénti TV-nézés ideje és a rendszeres testmozás között már szignifikánsnak hatott a kapcsolat Ezek szerint minél több idôt töltünk a TV elött, annál kevesebb idót fordítunk a testmozásra.

AZ UTAZASSAL KAPCSOLATOS

KERDESEK EREDMENYE

A hallgatók szabadidős tevékenységei közé tartozhat az utazás és kirándulás is. Három olyan kérdést tartalmaz ez a csoport ame lyekböl megtudhatiuk, hogy a hallgató mi alapián választia meg út célját, milyen gyakran engedheti meg magának ezt a kikapcsolódást, és milyen tevékenységeket szeret úzni utazása során.

Először az úti cél megválasztásának módját mutatom be, amelyet ábra formájában is bemutatok. Erre a kérdésre több választ is megjelölhettek a hallgatók.

Válaszlehetőségek

E kérdés eredményeiből az derül ki, hogy a megkérdezett hallgatók többsége igen árérzékeny. Diszkrecionális jövedelmük nem tesż lehetövé azt, hogy a Föld bármely pontjára szabadon elutazhas sanak. A megkérdezettek közül 89 fö számára fontos a kedvezó ár megléte egy desztináció kiválasztása során. Ez 59,3 százalóko tesz ki. Hasonloan fontos szerepet tôtenek be a kivalasztott úti col természeti adottságai, ugyanis 88 fiatal ezt jelölte válaszként. Ezek szerint sok megkerdezett szamára fontos, hogy a hely megfelelo tu
果

Abstract: In our article we have introduced the leisure activities and travel habits of 150 college students from Szolnok. We have analyzed the relationship between the frequency of watching $\mathrm{TV}$, that is: the time spent on watching TV and doing sports. Furthermore, we have also investigated the frequency of travelling, and the main motives of choosing travel destinations. We have found that college students have more hours of leisure time a day. Among the recreational activities predominantly such activities have occurred as watching $\mathrm{TV}$, doing sports, and travelling. It is interesting to note that the relationship between the frequency of watching TV and doing sports has not been significant while the relationship between watching $\mathrm{TV}$ occasionally and doing regular physical activity has turned out to be sighours a day spend significantly less time in front of the TV compared to their peers who do not play sports. $92 \%$ of the students travel at least once a year. The participants of youth tourism. are quite price-conscious. In choosing travel destinations favorable prices play an important role. Key words: free-time activities; youth tour-

ism; travel motives; pastime habits

isztikai vonzeróvel birjon. A tanulok figyelembe veszik korábbi ked vezỏ tapasztalataikat is, ugyanis 72-en (48\%) e válaszra voksoltak. Ebbol az derühnet ki, hogy a hallgatók egy része szeret visszatérn elölték meg ezt a választ ezért úgy gondolom, hogy számos fiata szeret új helyekre is ellátogatni, ahol korábban még nem járt. Nemcsak a saját tapasztalatikra, hanem más élményeire is sokan kiváncsiak. A megkerdezettek valamivel több, mint harmada (51 fö, 34\%) ismerósei, barátai véleményét is ki szokta kérni, mielött meghozza donteset, azaz tontos szamukra ismeróseinek ajanläasa. Mindossze 
13 fö $(8,7 \%)$ számára fontosak a prospektusokban leírtak. Ennél is kevesebben, kilencen annak alapján döntenek az úti cél kiválasztásáról, amit a TV-ben látnak. A hagyományos marketingkommunikációs eszközök szerepe csökken. Az interneten is sok információ található, az ún. szájreklám is szavahihető lehet, ha rokonoktól, ismerősöktől, barátoktól kaptuk az ismertetést.

Az utazási szokásokkal kapcsolatos kutatás igazolta a feltett hipotézist, mely szerint a kedvező ár jelentősen befolyásolja a fiatalok desztináció-választás motivációit.

Érdeklődtünk az utazási gyakoriságáról is.

Jól látható, hogy a fiatalok döntő többsége (138fő, 92\%) évente legalább egyszer tervbe vesz valamilyen utazást. Az eredményből az nem derül ki, hogy a hallgatók általában hány napra szeretnek elutazni valahova, de ez most kevésbé fontos. A lényeg az, hogy a megkérdezettek 36,7 százaléka (55 fő) évente egy alkalommal, 28,7 százaléka (43 fő) évente két alkalommal, 26,7 százaléka (40 fő) pedig évente három vagy még ennél is több alkalommal szokott kirándulni, utazni. Nyolc hallgató kétévente szokott kirándulni, utazni, négyen pedig ennél is ritkábban engedhetik csak meg maguknak. A mintában egy olyan megkérdezett sincs, aki soha nem tervez valamilyen kirándulást, utazást. Ezek szerint mindenki elismeri ennek az előnyeit, és igyekszik lehetőségéhez mérten bizonyos időközönként elutazni otthonról.

Az utazások alkalmával végzett tevékenységek iránt is érdeklődtünk. Érdekes eredmények születtek. 37-en, azaz a válaszadók 24,7 százaléka a kerékpárjukat is magukkal viszik utazásukhoz, ugyanis ennyien bicikliznek az utazások alkalmával. Természetesen az is előfordulhat, hogy a helyszínen bérelnek maguknak kerékpárt. Az is lehetséges, hogy kerékpárral közelítik meg az adott úti célt, és a helyszínen is terveznek kerékpáros programokat. A válaszadók pontosan 10 százaléka, azaz 15-en hódolnak a horgászatnak utazásuk során. 129-en, a válaszolók 86 százaléka szoktak strandra (is) menni. 114-en (76\%) választják a fürdőzést. Sokan terveznek még gyalogtúrát utazásuk során (69 fö, 46\%). Emellett még a természetben való kirándulásra is sokan „szavaztak” (96 fö, 64\%). A hallgatók saját válaszokkal is kiegészíthették a fentebb említett programokat. 33-an ezt meg is tették. Ezek közül a legtöbben a kulturális turizmusnak hódolnak (20 fő). Ebbe beletartozik többek között a helyi nevezetességek megtekintése, a városnézés, a múzeumlátogatás. Többen sportolnak utazás alatt: úszás, sielés, lovaglás. A sort néhány „extrémebb” sporttípus folytatja: búvárkodás, sziklamászás, vízisízés, kajak-kenu. Hatan kimondottan szórakozni is szeretnek az utazás alatt. Hárman wellness jellegü tevékenységeket próbálnak ki, mint például a szaunát vagy egy masszőr kezei alá fekszenek, hogy kipróbáljanak egy masszázstípust.

\section{ÖSSZEGZÉS}

A főiskolai hallgatók rendelkeznek napi több óra szabadidővel. A szabadidős tevékenységeik között dominánsan jelentkezik a tv-nézés, a sportolás, és az utazás. A nem sportszakos hallgatók többsége rendszeresen sportol szabadidejében. Így a szabadidős fogyasztást, mint tartós fogyasztási cikk, értelmezhetjük esetükben. Megcélozható szegmens a szabadidő-szolgáltatók számára. Bár elsősorban a költséghatékonyabb rekreációs tevékenységeket preferálják, de tartós igényt támasztanak ezen „termékek” iránt.

Az aktív életmód mellett azonban megfigyelhetők azok a szabadidős tevékenységek is, amelyek a „pihenés” körébe tartoznak, és ko- runk audiovizuális eszközökkel és az info-technológiával kapcsolatos, divatos tevékenységek: azaz a „TV, DVD, Filmnézés” az internetezés.

Észrevehetjük azt az érdekességet, hogy a gyakoriságnál nem, míg az alkalmankénti TV-nézés ideje és a rendszeres testmozgás között már szignifikáns a kapcsolat. Azok a hallgatók, akik naponta 1-2 órát sportolnak lényegesen kevesebb időt töltenek el a TV előtt azon társaikhoz képest, akik nem sportolnak.

Az ifjúsági turizmus növekvő keresleti trendjét támasztja alá ez a kutatás is, hiszen a vizsgált korosztály nagyobb része (92\%) igényt támaszt a különféle utazások iránt.

A fiatalok, mivel alacsony diszkrecionális jövedelműek, az utazási döntéseikben fontos szerepet játszik az utazás kedvező ára, alacsony költsége.

\section{FELHASZNÁLT IRODALOM:}

» Pikó Bettina (szerk.) [2005]: Ifjúság, káros szenvedélyek és egészség a modern társadalomban. Budapest, L'Harmattan Kiadó, 30. o. Az idézett mủ a továbbiakban: Pikó Bettina (szerk.) [2005]

" Barabás Katalin (szerk.) [2006]: Egészségfejlesztés. Budapest, Medicina Könyvkiadó Rt., 269-272.o. Az idézett mủ a továbbiakban: Barabás Katalin (szerk.) [2006]

" Szántó Miklós [1967]: Életmód, művelődés, szabadidő. Budapest, Akadémiai Kiadó, 13. o. Az idézett mű a továbbiakban: Szántó Miklós [1967]

» Reichlin Krisztina [2007]: Szabadidő ismeretek. Budapest, BGF Kereskedelmi, Vendéglátóipari és Idegenforgalmi Főiskolai Kar, 6. o.

" A szabadidő-turizmus [é.n.]. http://tavokt.kodolanyi.hu/ifodemo/ vendeglato/vendeg_lecke02.htm. Szerzők: Vizi István- Nagy László. Letöltés dátuma: 2009. október 11.

» Juray Tünde [2007]: A jövő utazói. Turizmus trend. 2007. június. 34-35. p.

"Ideális testsúly- pilates torna [2009]. http://www.idealistestsuly. hu/pilates.htm. Szerző: Takácsné Temesi Szilvia. Letöltés dátuma: 2009. október 15.

" A legfontosabb versenyszabályok [é.n.]. http://www.labtoll.hu/ Default.aspx?ID=sportagrol_jatekszabalyok.htm. Letöltés dátuma: 2009. október 15.

" Borbás László (2010): Fedezze fel az ifjúság világát! Szakdolgozat. Szolnoki Főiskola. Konzulens: Dr. Müller Anetta

"Wolfgang Nahrstedt (2000): Der Wellnessurlaub, Marktgerechte Angebote Gesundheitstourismus europäischer Kur-und Urlaubsorte, Heilbad und Kurort, 2000.08.171-173.p.

" Dumazider J. (1968): Some remarks on sociological problems in relation to physical education and sport. International Rewiew Sport Sociology. 3.pp. 5-18. 